\title{
RETÓRICA DA AGUDEZA
}

\author{
JOÃO ADOLFO HANSEN* \\ Faculdade de Filosofia, Letras e Ciencias Humanas \\ da Universidade de São Paulo
}

\begin{abstract}
RESUMO: O texto é uma exposição da doutrina seiscentista da agudeza. A agudeza é o efeito inesperado de sentido obtido pela condensação metafórica de conceitos extremos. Relacionando a prática da agudeza à racionalidade de Corte das monarquias absolutistas do século XVII, exemplifica com poetas, oradores e preceptistas, como Góngora, Gracián, Donne, Shakespeare, Gregório de Matos, Vieira, Tesauro, Pallavicino, Peregrini etc., a apropriação e a aplicação das autoridades retóricas gregas e latinas na produção do "belo eficaz".
\end{abstract}

PALAVRAS-CHAVE: racionalidade de Corte; retórica; metáfora; agude$z a$; conceito.

Nas preceptivas retóricas do século XVII, a agudeza é definida como a metáfora resultante da faculdade intelectual do engenho, que a produz como "belo eficaz" ou efeito inesperado de maravilha que espanta, agrada e persuade. A agudeza também pode resultar do furor e do exercício. Aqui, vou só falar das engenhosas, citando preceitos e exemplos de seus grandes teóricos seiscentistas, Matteo Peregrini, Sforza Pallavicino, Baltasar Gracián e Emanuele Tesauro. Quando definem suas várias espécies, propõem que a principal é a de artifício ou artificiosa, que busca a "formosura sutil". Aliás, o primeiro sinônimo do termo agudeza dado no Tesoro de la lengua castellana, editado em Madri em 1611 por Sebastián de Covarrubias Orozco, é "sutileza". Em Agudeza y Arte de Ingenio, de 1644, Gracián apresenta a seguinte definição dela: "Consiste, pois, este artifício conceituoso em uma primorosa concordância, em uma harmônica correlação entre dois ou três cognoscíveis extremos, expressa por um ato do entendimento" (Gracián, 1960, p. 239). Conforme Gracián, há três espécies de agudezas artificiosas:

1. agudeza de "conceito", que supõe a "sutileza do pensar", ou, especificamente, o ato do entendimento que descobre correspondências inesperadas entre coisas; 
2. agudeza de "palavra" ou "verbal", que consiste nas correspondências inesperadas estabelecidas entre as representações gráficas, sonoras e conceituais;

3. agudeza de "ação", relativa a sentidos agudos produzidos por gestos engenhosos.

A agudeza que resulta da comparação de conceitos é a mais perfeita, encontrando-se na base mesma da inventio retórica: ela é "raio" e "luz" gerados pelo "entendimento" do autor discreto. Na comparação dos conceitos, o juízo os decompõe dialeticamente, no sentido dado ao termo "dialética" no século XVII, "anatomia" ou "análise", para estabelecer semelhanças e diferenças entre eles. No caso, o juízo é perspicaz, penetrando nas mais recônditas partes dos conceitos analisados. Simultaneamente, a versatilidade do autor sintetiza as semelhanças e diferenças que foram achadas em uma forma nova e inesperada, que causa espanto ou maravilha. Essa forma é uma metáfora e, quando metáfora continuada, uma alegoria. Como a agudeza resulta de uma operação dialética, como análise, e de uma operação retórica, como elocução, tropo ou figura, os preceptistas do século XVII costumam chamá-la de "ornato dialético". E, quando é hermética, como ocorre na poesia magnífica de Góngora, "ornato dialético enigmático".

Bom exemplo de agudeza verbal é o caso narrado por Baldassare Castiglione em Il Libro del Cortegiano, de 1528, sobre um fidalgo castelhano que, vendo entrar na sala do trono um casal nobre vestido com roupas de damasco branco, o marido feíssimo e a mulher belíssima, diz para a rainha Isabel, a Católica: "Esta é a dama, aquele o asco". A expressão é aguda, pois resulta da decomposição ou anatomia da palavra "damasco" em dois conceitos metafóricos, "dama" e "asco", apropriados engenhosamente à ocasião. Exemplo de agudeza de ação podia ser aqui o de outro espanhol, que comandava um dos navios da armada que veio a Pernambuco em 1640 para combater os holandeses de Maurício de Nassau. Seu barco bate em um recife e faz água; enquanto a tripulação foge, ele abre o livrinho das Metamorfoses e começa a comentar com o imediato o sentido de uma metáfora, afundando com Ovídio. Segundo a opinião dos contemporâneos, ele aproveitou a ocasião para fazer agudamente bem o que de qualquer modo sempre acontece depois, nunca se sabe se mal. Um exemplo de agudeza que se pode achar na correspondência de objetos é o de um Acto Especulativo e Practico realizado numa academia de Medicina da Universidade de Coimbra, em 3 de fevereiro de 1733, em que foram feitas anatomias do Sol, da Lua, do Ar, da Luz e dos Olhos. Uma das proposições defendidas afirma o seguinte: "Aclara-se que a luz é cousa obscuríssima”, demonstrando-se que a luz visível, claríssima, é sombra, por ser emanação ou criação de Deus, ao passo que o próprio Deus, por ser perfeito, é luz absoluta, 
mas invisível, e, logo, escuríssima. Mais um exemplo de agudeza, que mistura voz e gesto e agrada muito, pois ao mesmo tempo move dois sentidos, é dado pelo conde Emanuele Tesauro no seu tratado sobre o conceito engenhoso, Il Cannocchiale Aristotelico, de 1654, ele mesmo um texto agudíssimo, pois Tesauro afirma tê-lo escrito seguindo uma analogia de proporção: assim como Galileu aplicou a luneta recentemente inventada na Holanda à observação dos planetas, seu tratado a aplica à Retórica aristotélica, para ver de perto o que o filósofo viu de longe, amplificando o que no texto do grego é pequeno e observando várias vezes o que viu uma só. A agudeza de que falei é o exemplo de um histrião que, recitando para Nero e o Senado reunidos um verso patético de um poeta antigo,

\section{Heu mi Pater. Heu mea Mater. Orcus vos tenet,}

ao dizer Heu mi Pater, acompanhou as palavras com gesto de pessoa que bebe. E, dizendo Heu mea Mater, fez o gesto de pessoa que nada, aludindo com eles aos dois crimes de Nero, o do envenenamento do padrinho e o da mãe afogada. Dizendo depois Orcus vos tenet, ergueu a voz e apontou Nero aos senadores, como se dissesse Eis o demônio que vos domina, sendo muito aplaudido. Pela agudeza de um gesto, um fato digno de lágrimas tornou-se ridículo.

$$
* * *
$$

Nas práticas de representação do século XVII, há outros nomes para o ornato dialético ou agudeza: conceito, concetto, concepto, conceito engenhoso, argúcia, argutezza, acutezza, wit, Witz, pointe, entimema e silogismo retórico. Então, sua doutrina e sua prática são internacionalizadas e reciclam a Retórica aristotélica (principalmente o Livro III, 1450, que trata da elocução) e a Poética, XXI, além de vários autores latinos. Basicamente, a doutrina retoma o pressuposto aristotélico, exposto no De anima, de que qualquer discurso é por natureza metafórico, pois os noeta, os conceitos, são imagens mentais que substituem os aistheta, os objetos da percepção. Os signos verbais, orais e escritos, são entendidos como imagens das imagens mentais. Aristóteles também diz em outro lugar que são próprias do orador e do poeta as metáforas que tornam a obra aguda: "Agudas, pois, são as expressões do pensamento que permitem um aprendizado rápido" (Arist.,1410 b). Produzida proporcionalmente pelo engenho, a agudeza convém ao discurso civil: aristotelicamente, ela é astéia, termo traduzido por urbanitas, em Roma. No século XVII, ela define a civilidade ou o estilo próprio do cortesão. 
A agudeza deve ser formulada rapidamente, porque só tem efeito se a premeditação não for evidente; obtém-se a rapidez eliminando-se o conectivo da comparação dos conceitos, a prótase da similitude, "como". Por exemplo, vamos supor a comparação "Esse papagaio do Brasil é verde como o mês de abril da Europa", em que se compara o conceito /papagaio / com o conceito /abril/ por meio do conceito /verde/, que é um gênero comum a ambos. A comparação, no caso, implica 3 termos: A (papagaio) $-B$ (verde) $-C($ abril): "Esse papagaio é verde como abril". Se eliminamos a prótase da similitude, o conectivo "como", podemos dizer: "Esse papagaio é abril", e, assim, pela equivalência - "A é B", substituir o termo A("papagaio") por B("abril”): "Esse abril”. Como se trata de /papagaio/, podemos propor, com agudeza: "Esse abril falante", como encontramos em um poema da Fênix Renascida, a grande antologia da poesia da agudeza feita em Portugal no século XVIII. A imagem resultante é algo nonsense, como toda metáfora, mas agrada justamente pela dificuldade inicial de estabelecer a relação imediata entre os conceitos. A imagem obtida é um entimema ou um silogismo retórico, como diz Quintiliano, quando retoma os Analíticos de Aristóteles (I,II,27, 70a 10): uma dedução baseada na semelhança de dois termos com um terceiro. Funciona como uma condensação rápida deles, efetuada como metáfora engenhosa pela analogia de atribuição: $A: B: C$.

O Anônimo da Retórica para Herênio (IV, 19) e Cícero ( Partitiones oratoriae VI,18,22; De oratore III) escrevem que o discurso ilustre ou brilhante é obtido pelo uso de palavras escolhidas (delecta), de metáforas( traslata), de hipérboles (supralata) e de sinônimos (duplicata). Tais palavras produzem a evidentia ou a visualização imaginosa da matéria tratada no discurso. De novo, Aristóteles: para estimular o pathos em si mesmo e nos ouvintes, o orador que pretende qualificar determinado assunto produz representações chamadas phantasiai (Retórica, I,3,1358b). Retomando Aristóteles e Cícero, Quintiliano escreve, na Institutio oratoria 6,2,29, que as imagens fantásticas são produzidas pelo engenho e que este é cultivado com o exercício da imitação das auctoritates dos vários gêneros. A figura das fantasias é a evidentia, como disse, feita como descrição detalhada de um objeto por meio da enumeração ornada de suas particularidades reais ou fantásticas. Na representação do século XVII, a evidentia é preferencialmente aguda. Por exemplo, no início da Soledad Primera, como sabem, Góngora figura Júpiter com imagens que nos fazem ver um touro que apascenta estrelas num campo de safira:

Era de el año la estación florida en que el mentido robador de Europa

- media luna las armas de su frente, 
y el Sol todos los rayos de su pelo-,

luciente honor del cielo,

en campos de zafiro pasce estrellas.

Mais um belíssimo exemplo de evidentia engenhosa é o produzido por Vieira como alegoria de hipócritas, no sermão de Santo Antônio, que pregou no Maranhão em junho de 1654. Ouçam, por favor, como vai desdobrando o termo "polvo" em imagens, para depois fornecer ao ouvinte o sentido que as interpreta:

[...] temos lá o irmão polvo, contra o qual tem suas queixas, e grandes, não menos que São Basílio e Santo Ambrósio. O polvo com aquele seu capelo, parece um monge; com aqueles seus raios estendidos, parece uma estrela; com aquele não ter osso nem espinha, parece a mesma brandura, a mesma mansidão. E debaixo desta aparência tão modesta, ou desta hipocrisia tão santa, testemunham contestamente os dous grandes Doutores da Igreja latina, e grega, que o dito polvo é o maior traidor do mar. Consiste esta traição do polvo primeiramente em se vestir, ou pintar das mesmas cores de todas aquelas cores, a que está pegado. As cores, que no camaleão são gala, no polvo são malícia; as figuras, que em Proteu são fábula, no polvo são verdade, e artifício.

$$
* * *
$$

No século XVII, os preceptistas afirmam não só que a agudeza é metáfora, mas, principalmente, que a metáfora é o próprio fundamento da agudeza e, de modo geral, de toda representação. Como se lê no tratado de Tesauro, a metáfora é:

[...] Grande Mãe de todo engenhoso Conceito: claríssimo lume da Oratória, \& Elocução Poética: espírito vital das mortas Páginas: agradabilíssimo condimento da conversação Civil, último esforço do Intelecto: vestígio da Divindade no ânimo Humano (Tesauro, 1670).

As doutrinas italianas e ibéricas da agudeza dos séculos XVII e XVIII que circularam nas colônias espanholas e portuguesas da América, principalmente por meio das ordens religiosas, como a Companhia de Jesus - e novamente lembro os tratados de Matteo Peregrini, Sforza Pallavicino, Emanuele Tesauro, Baltasar Gracián, Francisco Leitão Ferreira - são uma interpretação neo-escolástica de Aristóteles e de autores latinos. Todas elas incluem-se na racionalidade de Corte das monarquias absolutistas e 
propõem a agudeza como a forma própria das maneiras de falar e agir do cortesão. Lembro, com isso, que a agudeza deve ser entendida como uma categoria histórica, ou seja, como um modo de pensar e uma forma poética específicos do Antigo Regime, não como a futilidade afetada e vazia de que ainda vão falando os nossos manuais de história literária caudatários do idealismo alemão.

Acredita-se no século XVII que o intelecto humano é um espelho sempre idêntico a si mesmo e simultaneamente sempre vário, que exprime imagens dos pensamentos das coisas postas à sua frente. Assim, o discurso interior do pensamento é entendido como um contexto ordenado de imagens chamadas fantasmas, que existem na mente antes da representação exterior; quando os fantasmas são exteriorizados, o discurso e outras formas são definidos como ordem de signos sensíveis copiados das imagens mentais como tipos do arquétipo. Por isso, os signos, em geral, são entendidos como "definição ilustrada", como encontramos no prefácio do tratado de Cesare Ripa, Iconologia, de 1593. Obviamente, as representações de que falo não são cartesianas, por isso não fazem distinção entre conceito e imagem. Todo signo é então definido como a metáfora que relaciona o pensamento e a sua representação exterior, ou, em termos seiscentistas, como a metáfora que relaciona a "argúcia arquétipa" e suas formas exteriores. As formas exteriores- pintura, escultura, poesia, música, dança, emblemática, vestuário, cores, gestos etc. - são classificadas segundo o sentido antigo de graphein, verbo relativo à faculdade do desenho, significando-se com a noção de "desenho" a forma interior ou o "desenho interno" que se produz na consciência quando esta é iluminada pela luz da Graça inata.

$\mathrm{Na}$ representação, as metáforas exteriores dramatizam o "desenho interno" como a virtù visiva dos preceptistas italianos do século XVI, aplicando-se agudamente a técnica romana de evidentia por meio de letras, sons, linhas, volumes, cores e gestos. Fala-se então que a pintura realiza o desenho interno por meio da aritmética, da geometria e da óptica, como commensuratio ou proportio, para produzir o fingimento de sombras, cores e volumes, enganando a vista do espectador pela perspectiva que faz com que coisas distantes pareçam menores e vice-versa, da mesma maneira como a poesia e as outras artes do discurso calculam, com proporção, os efeitos visualizantes que movem os afetos. $O$ pintor grego Timantes teria figurado o dedão do pé de Polifemo com a mesma altura das colunas de um templo. A sinédoque de Timantes é engenhosamente aguda: vendo apenas a parte monstruosa, o observador imaginaria a dimensão total do corpo ausente do cíclope e o espanto lhe proporcionava prazer intelectual, pois também se maravilhava com o engenho e o artifício do pintor. 
Como disse, a metáfora aguda evidencia para o destinatário a excelência do juízo do autor iluminado pela luz da Graça no estabelecimento de relações inesperadas entre coisas e palavras. No caso, o destinatário capaz de refazer o processo de construção da agudeza é tão perspicaz e versátil, ou seja, engenhoso, como o autor; por isso, nas sociedades de Corte do século XVII, a agudeza era um dispositivo político que conferia distinção. Ou seja: as práticas seiscentistas da agudeza não são "barrocas", como são classificadas hoje; e nelas não há nenhuma noção modernista, moderna, vanguardista ou já pósutópica de autonomia das artes ou de estética. Nelas, como disse, a representação exterior imita as articulações do pensamento, que são as das coisas, as res da inventio; por isso mesmo, as artes que operam com agudezas pressupóem uma lógica da imagem, sempre definida como a imagem retórica que funciona nas obras como um argumento sensível aplicado ao desenvolvimento das tópicas. No ato da invenção, quando o poeta improvisa oralmente ou escreve, a forma do conceito interior da sua mente é recortada em uma matéria, som da voz ou letra escrita com pluma de ganso. A forma também poderia ser recortada em uma substância plástica, como pintura ou escultura, desde que obedecesse aos mesmos critérios miméticos do gênero. Os processos da inventio e da elocutio fundamentam não uma "estética", que pressupõe a psicologia do autor, a autonomia estética e a livre-concorrência da obra no mercado como a mercadoria "originalidade" apropriada por públicos dotados de autonomia crítica, mas uma técnica, que é um saber-fazer ou uma ciência retórica dos preceitos, procedimentos técnicos e efeitos verossímeis e decorosos específica da racionalidade não-psicológica da mímesis aristotélica reciclada neoescolasticamente. Dizendo de outro modo, o conceito representado exteriormente é o resultado de um juízo que atua no engenho como causa eficiente da imagem mental. Vejamos um exemplo dado por Gracián:

[...] juntou [...] Ovídio, em uma pedra chamada oníx em latim, e no nosso castelhano cornarina, este mote: Flamma mea, e a enviou assim sobrescrita, querendo dizer : O, nix, flamma mea!, que ainda em romance diz agudeza: "Oh, neve, chama minha!” (Gracián, 1960, II).

Ovídio é agudo porque decompõe, no vocativo: $O$, nix, com que se dirige à amante, chamada Nix, /neve/, o nome da pedra: onix. E escreve, na mesma pedra, o termo flamma, chama, associado às noções de /fogo/e /calor/, em oposição a nix, termo associado às noções de /brancura/ e /frio/. Com isso, além de /frio/quente/, produz outro contraste, /preto/branco/, ambos adequados a Eros. 
T. S. Eliot dizia sobre a poesia metafísica inglesa que os autores do século XVII possuíam um mecanismo de sensibilidade que podia devorar intelectualmente qualquer espécie de experiência. Segundo Eliot, as imagens produzidas por poetas como Donne são caracterizadas por uma compulsão da semelhança, que faz com que construam o poema como harmonia de dissonâncias. Nesse mesmo sentido, podíamos dizer que também outros grandes poetas do século XVII, como Góngora, Quevedo, Marino, D. Francisco Manuel de Melo, Sor Juana Inés de la Cruz, Honoré d'Urfé, Andreas Gryphius, Shakespeare, Marvell, Gregório de Matos, estavam empenhados, em maior ou menor grau, em encontrar equivalentes verbais para os mais variados estados da mente e dos afetos. Por isso, toda metáfora que produzem é intelectual; as paixões são naturais, mas não informais, porque sua codificação é retórica; por isso, também as agudas baseiam-se em temas e termos já conhecidos do costume anônimo, ou seja, em elencos de tópicas, formas e gêneros armazenados como uma memória coletiva de usos autorizados. Os poetas sempre buscam a novidade da elocução engenhosa, mas as tópicas com que trabalham fazem parte do todo social objetivo. Geralmente, vão do conceito mais geral que se faz do tema para conceitos por assim dizer periféricos, que tornam a leitura do poema um exercício de dificultação crescente. $O$ poema sempre corre o risco da incongruência, mas, tratando-se de grandes poetas, a dificultação é intelectualmente controlada: mesmo as incongruências resultam de um cálculo. Assim, o intervalo semântico entre a noção abstrata ou conceito e a metáfora que a representa exteriormente pode ser maior ou menor - quanto maior for o intervalo, maior a novidade da combinação de coisas já conhecidas. Afinal, como lembrava Ricoeur, só há persuasão a respeito de coisas já conhecidas. A idéia geral dos poetas e preceptistas do século XVII é a de que o espírito literalmente cai, quando é posto em contato direto com a chateza e a chateação da verdade nua. Logo, Góngora. Como no jogo de xadrez, quando ocorre um lance inesperado, mas totalmente previsto por convenções, as metáforas agudas operam em um intervalo semântico que as torna tendencialmente herméticas; como disse, sempre obedecem a regras. Nenhuma psicologia, nenhum expressivismo, mas sempre a demonstração de uma idéia prismaticamente dividida, redividida e metaforizada por seu gênero, espécies e acidentes. A poesia da agudeza é, quase sempre, uma expansão do discurso para zonas laterais e inesperadas de significação. Por exemplo, em um dos sonetos de Música do Parnaso, Manuel Botelho de Oliveira trata do amor de Anarda, sua musa, escrevendo: "A serpe, que adornando várias cores, / com passos mais oblíquos que serenos,/ entre belos jardins, prados amenos,/É maio errante de torcidas flores". Ele compara "serpe" e "maio", o réptil com o mês, por meio de uma metáfora de proporção pela qual A:B::C:D: serpente está para movimento físico assim como maio está para movimento temporal. Outro exemplo: Andrew Marvell, em "The Coy Mistress", propõe à amante tímida que, se tivessem mundo e tempo suficientes, o recato dela não seria crime; declarando em seguida 
que a amaria dez anos antes do Dilúvio e que ela, se isso a agradasse, continuaria recusando-se a entregar-se a ele até a conversão dos Judeus, declara: "My vegetable love should grow/ Vaster than empires and more slow..." versos em que o amor é vegetal que cresce, verde-erótico da esperança mais vasta que os impérios, e mais lento. No caso, o leitor tem que descobrir qual é a relação semântica entre o adjetivo e nome em "vegetable love". Ela não é imediatamente evidente, apresentando-se com certa indeterminação conceitual; mas sua evidência sensível impõe-se como natural. Outro exemplo: Góngora, em um soneto de 1583 dirigido a uma dama, propõe-lhe que goze o corpo e várias partes dele, enquanto é tempo, pois o ouro polido do cabelo, o lírio da face, o cravo dos lábios etc. se transformarão em violeta truncada, imagem que condensa as rugas da velhice e o roxo católico das exéquias, alertando-a de que tudo será terra, pó, cinza, fumo, nada. Um dos sonetos da lírica atribuída a Gregório de Matos o imita; nele, a persona lírica dirige-se a uma dama chamada Maria. Para figurar a passagem do tempo e a morte no fim de tudo, substitui a transformação dos lírios e cravos da juventude na violeta da velhice, que encontramos em Góngora, pela figuração de um cavalo que trota, pisando cruelmente flores: "goza da flor da mocidade/ que o tempo trota a toda ligeireza/ e imprime em toda flor sua pisada". Mais um exemplo: em Romeu e Julieta, Shakespeare figura a aproximação dos amantes por meio da alegoria de crianças felizes que fogem dos livros escolares; simetricamente, a separação é o olhar de crianças que vão à escola com ar pesaroso : "Love goes toward love as school-boys from their books/ But love from love, toward school with heavy looks" (Shakespeare, Romeo and Juliet, II, II).

Todas as metáforas desses versos são agudas, algumas agudíssimas; sua avaliação contemporânea considerava, antes de tudo, se estavam de acordo com os preceitos técnicos da arte, ou seja, se estavam adequadas à verossimilhança e ao decoro específicos do gênero das composições em que aparecem. Por outras palavras, a mesma agudeza podia ser classificada como inépcia e seu efeito de novidade seria tido como afetação. Em todos os casos, o desempenho apto da agudeza caracteriza a emulação bem feita. Como sabem, a emulação é a imitação que supera o modelo imitado. É o que escreve Emanuele Tesauro:

Chamo pois imitação uma sagacidade com a qual, quando para ti é proposta uma metáfora ou outra flor do humano engenho, consideras atentamente as suas raízes e, transplantando-a em diferentes categorias como em um solo cultivado e fecundo, propagas outras flores da mesma espécie, mas não os mesmos indivíduos (Tesauro. Arguzie umane. Il Cannocchiale Aristotelico; 1670). 
Basicamente, a emulação visa a produzir, por outros modos e por outros meios, um prazer semelhante ou superior ao da obra imitada. Para isso, pretende produzir agudezas mais agudas que as da obra imitada. Definindo a emulação, o cardeal Sforza Pallavicino propõe, em seu Arte dello Stile, ove nel cercarsi dell' Ideal del scrivere Insegnativo, de 1647, um exemplo fornecido por Platão: na invenção da fábula, nos lugares em que os caracteres aparecem maiores, pode-se refigurá-los, mas como caracteres diminuídos, mantendo-se a mesma fábula. Assim, obviamente, há regras para emular os autores sem roubá-los ou meramente imitá-los. A primeira delas, como regra universal, consiste em procurar qual é a propriedade ou o predicado que produz prazer na obra que se vai emular. Pallavicino adverte que tal predicado é um gênero comum que inclui espécies muito diversas de invenções possíveis. Depois que se descobre o gênero, o passo seguinte é encontrar, com o engenho, uma das espécies que seja semelhante à obra imitada quanto ao predicado, duma parte, e que, pelo fato de ser apenas semelhante, seja também diferente. A diferença deve ser de tal sorte que faça com que o predicado encontrado participe mais e melhor nela. Assim, o modo de produzir semelhanças e diferenças agudas distingue emulação de imitação servil, que lembra a imitação escolar.

Segundo esses critérios, as preceptivas seiscentistas são formuladas como uma lógica de tópicas da invenção e da disposição e uma técnica da sua elocução aguda. Por exemlo, em 1639, em seu Delle Acutezze, Sobre as Agudezas, de que pretendo falar adiante, Matteo Peregrini propõe muito minuciosamente " 25 cautelas para o uso das agudezas"; em 1644, Baltasar Gracián formula, em seu Agudeza y Arte de Ingenio, várias "crisis", análises, definições e exemplos de gêneros, espécies e circunstâncias da agudeza. Mas é certamente Tesauro, em Il Cannocchiale Aristotelico, que dilata a proposição modelar das tópicas, sistematizando a teoria da agudeza como teoremi pratici, teoremas práticos, que permitem, como afirma, produzir e usar as metáforas agudas com proporção.

Para formular seus "teoremas práticos", Tesauro compõe um "índice categórico", uma tabela, recorrendo às dez categorias aristotélicas. A aplicação engenhosa das categorias permite formular ditos agudos, pois o engenho é a capacidade intelectual de penetrar nas coisas da inventio por meio delas. São dez, como sabem: substância, quantidade, qualidade, relação, ação, paixão, situação, tempo, lugar e hábito. Cada uma delas, quando aplicada a um tema determinado, permite fazer uma definição e, ao mesmo tempo, uma variação elocutiva dele. Por isso, a agudeza é definida por Tesauro como "ornato dialético" ou imagem produzida como síntese rápida de uma ou de várias análises categoriais dos conceitos descobertos no tema tratado. Citando exemplos dados por Tesauro, passo a falar das categorias e dos seus usos agudos. 
Tesauro explica que, sob a categoria de substância, vem Deus, ainda que esteja acima de toda categoria: as divinas pessoas da Trindade; a Idéia; os deuses fabulosos. Os deuses celestes, aéreos, marinhos, terrenos, infernais; os heróis, homens deificados. Anjos e demônios. O céu e as estrelas. Os signos celestes e as constelações, ou imagens da oitava esfera. O Zodíaco e todos os círculos e esferas imaginários Os quatro elementos, os vapores, que são fumos quentes, e as exalações, frios. $O$ fogo, a esfera ígnea, os fogos subterrâneos. $\mathrm{O}$ ar e seus meteoros, estrelas cadentes, cometas, raios, ventos, neves, chuvas. A água e os mares, rios, fontes, lagos. A terra, campos, prados, solidões, montes, colinas, promontórios, vales, precipícios. Os corpos, mistos inanimados, pedras, mármores, gemas, metais, minerais, plantas, ervas, flores, árvores, arbustos, corais. Animais terrestres, feras, e aquáticos, e aéreos, pássaros, e os monstros. Homem, mulher, hermafrodita... Existe também a substância artificial, ou as obras de toda arte: nas ciências, livros, penas, tintas; na matemática, globos, mapas-mundi, compassos, esquadros. Na arquitetura, palácios, templos, tugúrios, torres, fortalezas. Na arte militar, armas, escudos, espadas, tambores, tubas, cornetas, bandeiras, troféus. Na pintura e escultura, quadros, pincéis, cores, estátuas, escalpelos. Além da substância física, o engenho também considera a substância metafísica, como o Gênero, a Espécie, a Diferença, o Próprio, o Acidente em geral: o nome, o cognome e noções semelhantes. Aqui, Tesauro dá um pequeno aviso: as metáforas de acidente são mais convenientes que as metáforas de substância, porque implicam relações mais adequadas à representação visualizante própria da evidentia.

Ainda, sob a categoria de quantidade, o engenho deve considerar a quantidade do tamanho: pequeno, grande; longo, curto. A quantidade numérica: nenhum, um, dois etc., muitos, poucos. A quantidade de peso: leve, pesado. A quantidade de apreço: precioso, vil. E a quantidade em geral: medida, parte, todo: perfeito, imperfeito: finito, infinito, divisível, indivisível, proporcionado, desproporcionado, maior, menor, igual etc. Pela categoria qualidade, são inventadas imagens que pertencem à visão: visível, invisível, aparente; belo, disforme; claro, obscuro: branco, negro, púrpura etc. Ou que pertencem à audição: som, silêncio, som harmônico e desarmônico. Ao olfato: suave, forte. Ao gosto: saboroso, insosso etc. Ao tato: quente, frio, seco, úmido, liso, áspero etc Aqui, temos também as qualidades figurais : direito, torto, redondo, quadrado, agudo, obtuso etc. E o que Tesauro chama de qualidades exteriormente denominantes: fama, infâmia; honra, desonra, fortuna, infortúnio. Ou as qualidades internas naturais: são, doente, prazeroso, doloroso. Também existe a qualidade de paixões: alegria, tristeza, amor, ódio, esperança, medo. Equalidades intelectuais: sabedoria, ignorância, arte, inépcia. E, obviamente, qualidades morais: a virtude e a infinitude dos vícios. 
A categoria de relação dá conta do parentesco e da companhia, da amizade e simpatias, das inimizades e antipatias, dos semelhantes, dos contrários, dos opostos, do superior, do inferior e também das causas das coisas: causa eficiente, efeito, causa material, forma, causa final, privação, nomes, títulos, verdade e falsidade. Com as categorias de ação e paixão podemos pensar em: potente, impotente: fácil, difícil: nocivo, inofensivo: útil, danoso etc. E em operações naturais: nutrir, produzir. Em operações políticas: reinar, julgar, guerrear, tiranizar. Em ações mecânicas: fazer, desfazer, cansaço, ócio, calma. Em ações cerimoniais: festivas, fúnebres, sagradas etc. Quanto à categoria de situação, lembramos : alto, baixo, plano, jacente, pendente, cruzado, direito, esquerdo, médio, dentro, fora etc. E a com a categoria de tempo: momentâneo, durável, novo, velho, principiar, acabar. Quanto à de lugar: pleno, vazio. Movimento: veloz, lento, direito, oblíquo: de um lugar, por um lugar, perto de um lugar, em direção a um lugar etc. Quanto ao ter, ou à posse: rico, pobre; vestes, empresas, divisas, armas, ornamentos, instrumentos.

A aplicação das dez categorias aristotélicas a um tema determinado permite inventar dez definições ilustradas ou conceitos básicos, como disse; ao mesmo tempo, a versatilidade do autor encontra, para cada um dos conceitos obtidos, uma metáfora adequada, a cada vez mais semanticamente distante, para produzir o espanto. Como dizia Marino com um hipérbato maravilhoso, "é do poeta o fim a maravilha”. O espanto pode ser intesificado, pois a combinação das categorias, que traduz cada uma das dez metáforas iniciais por outras semanticamente mais distantes, produz formulações agudíssimas. Imaginemos, por exemplo, que vamos compor um poema de gênero baixo e que resolvemos aplicar o termo anão para caracterizar o personagem como tipo ridículo. Quando examinamos o termo repassando-o pelas categorias - por exemplo, a categoria quantidade, que é a primeira das acidentais - podemos achar inúmeras metáforas de coisas pequenas em coisas elementares, como "átomo" e "grão de areia"; em coisas humanas, como "pigmeu" e "unha"; em animais, como "formiga", "pulga", "mosca", "ácaro", "escama de peixe" etc; em plantas, como "grão de trigo", e, ainda, em objetos; entre eles, os militares, como "umbigo do escudo" etc. Por meio da categoria quantidade, podemos dizer, por exemplo, "Esse umbigo do escudo" para significar "Esse anão".

A formulação é aguda, mas também bastante hermética e, por isso, corre o risco de ser apenas incompreensível. No século XVII, o hermetismo não era sempre um defeito, como hoje, pois também distinguia os engenhosos capazes de produzir e entender a agudeza. Góngora foi acusado por seus inimigos, como Jáuregui, Quevedo e Lope de Vega, de ser obscuro e incongruente nas Soledades, pois tratou um assunto humilde em estilo sublime. Como sabem, respondeu ter desejado escrever escuríssimo, 
em grego, declarando "escribo no para muchos", para afirmar a concepção tipicamente aristocrática segundo a qual o engenho inventa coisas agudas próprias para agudos, não para vulgares. Como sabem, data de 1624 a cunhagem do termo "culterano", que relaciona "culto" e "luterano", usado para classificar a poesia de Góngora como heresia poética. Mas disso falamos depois, se for o caso. Saio agora de Góngora e desço novamente ao "anão".

Quando repassamos todas as coisas pequenas necessárias para inventar metáforas adequadas à representação do tema, é mais conveniente inventar uma formulação ainda mais engenhosa e de maior dificuldade. Por exemplo, juntamos a um termo inventado pela categoria quantidade outro termo inventado por meio de outras categorias. Assim, quando já repassamos o índice "pequeno" por todas as classes que pudemos achar da categoria quantidade, nós o cruzamos com outras classes obtidas por meio das outras categorias. Com termos da mesma categoria quantidade, podemos dizer, na comédia ou na sátira, que "Esse umbigo do escudo é uma pulga". Os gêneros baixos admitem, por definição, essas incongruências inverossímeis que se tornam verossímeis para figurar a desproporção dos vícios e tipos viciosos. Os seiscentistas as chamavam de "inconveniências convenientes". A mesma metáfora "pulga", por exemplo, pode ser a base de novas metáforas ou de novos poemas. No de John Donne, "The Flea", "A Pulga", o animal é traduzido pela metáfora "escuro templo", porque sugou o sangue do homem que fala à mulher também picada; como o casamento é fusão de sangues e os sangues de ambos estão misturados no interior do animal, estão casados; e como o casamento costuma ser oficiado em templos, a "pulga" que os picou é um "templo".

Tesauro acompanha as receitas de duas advertências: a primeira é a de que nem todas as partes encontradas pela aplicação das categorias são sempre combináveis entre si de modo prazeroso, útil e persuasivo, devendo-se evitar a mala affectatio, a afetação e a decorrente frieza. A não ser nos gêneros baixos ou cômicos, como disse, em que a inverossimilhança é aplicada de propósito, pois o excesso é verossímil para representar a falta de unidade dos vícios. Em um poema contra o governador Sousa de Meneses atribuído a Gregório de Matos e Guerra, a persona satírica afirma: “O que te vir ser todo rabadilha/ dirá que te perfilha uma quaresma, chato percevejo”, traduzindo a figura do governador por "rabadilha", termo que significa o cóccix da galinha, aquele lugar onde nascem as penas da cauda da ave. É uma figuração sórdida e obscena, que nos faz ver um cóccix que, enquanto anda, encolhe-se, pois está sendo chupado por um percevejo. No caso, a imagem do governador como "rabadilha" corresponde à categoria aristotélica substância material, que o poema vai cruzando com outras. A segunda advertência de Tesauro é complementar: não se deve ficar totalmente preso ao índice e à ordem das partes das categorias, pois elas podem ser misturadas, antepos- 
tas ou pospostas. No caso, é o juízo dos autores das agudezas que deve ser o "companheiro indivisível do engenho" (Tesauro, 1670, p. 112). Por exemplo, o mesmo poema atribuído a Gregório mistura as categorias hábito, qualidade e quantidade, para figurar o governador como um tipo vulgar, subserviente e puxa-saco, o típico porteiro de palácio que conhecemos aqui e lá: "O rabo erguido em cortesias mudas/ Como quem pelo cu tomava ajudas". Os versos talvez fiquem ainda mais divertidamente agudos, se nos lembramos de que no século XVII o termo "ajuda" também significava "clister".

Assim, na poesia da agudeza, uma coisa ou tópica da invenção pode ser significada por meio de três espécies de signos e relações: $1^{\mathrm{a}}$. por mera convenção; $2^{\mathrm{a}}$. pela relação de inclusão ou sinédoque entre a coisa significada e a significante; $3^{\text {a }}$. pela semelhança entre elas. Pela simples convenção, propõe-se a relação arbitrária de signos que inicialmente não têm relação: por exemplo, assim como um traje vermelho representa a guerra, é muito usual o uso das "metáforas fósseis", como "cristal", que pode significar qualquer coisa lisa, transparente, úmida, fria ou líqüida: água, céu, rosto, olhos, vidro, espelho,neve e cristal. Pela segunda relação, têm-se duas coisas que não têm semelhança entre si, mas que podem ser juntadas em um gênero comum, como causa, conseqüência, instrumento, hábito etc. É o caso de sinédoques alegorizantes, como a espada pela guerra, a pena pela doutrina, o arado pela agricultura etc. A terceira é propriamente a relação de semelhança. Com ela, propõem-se duas coisas semelhantes entre si, ambas físicas, ou uma física e outra moral, ambas animadas, ou uma animada e outra inanimada etc. Quanto à própria semelhança, pela qual um signo é substituído por outro, pode ser de três espécies, de atribuição, de proporção e de proporcionalidade. Assim, por atribuição, tem-se a semelhança de duas coisas que participam em uma única forma, chamada "unívoca"; por proporção, a semelhança de duas coisas que não têm uma forma comum, mas duas formas proporcionalmente análogas; por proporcionalidade, tem-se a mesma relação de proporção, mas operada com conceitos distantíssimos, que são entendidos como alegorias ou enigmas que correspondem às anamorfoses da pintura. Pela primeira dessas relações, os poetas aproximam coisas diferentes em essência, mas semelhantes segundo uma propriedade qualquer em comum; por exemplo, o lírio e a neve, segundo a brancura; ou o fogo e o amor, fisicamente impetuoso o primeiro, moralmente o segundo, com transferência de espécie a espécie: fala-se do amor como "fogo do peito", do lírio como "neve do prado", da neve como "lírio do inverno". São as segundas e as terceiras, porém, as metáforas de proproção e de proporcionalidade, que exigem maior engenhosidade, pois aproximam duas coisas diversas, dando mais prazer ao destinatário quando este é apto para entender as operações artificiosas que condensam em um sentido duas coisas até então distantíssimas. Na Bahia do final do XVII, segundo o franciscano Frei António do 
Rosário, em um sermão em que pregou a doçura do amor de Cristo em forma de metáforas de vinte e cinco frutas tropicais, o ananás e a expressão latina Anna nascitur se relacionam por proporcionalidade; em Gregório de Matos, tempo e cavalo, no poema que referi, relacionam-se por proporção, por meio da metonímia trota - "o tempo trota a toda ligeireza/ e imprime em toda flor sua pisada". Entre as metáforas, o poeta engenhoso prefere a metáfora de proporção, pela qual "o copo é o escudo de Baco", assim como "o escudo é o copo de Marte", como se pode ler na Poética. A metáfora de proporção evidencia a "erudição de coisas distantíssimas", como prescreve Tesauro

$$
* * *
$$

Como disse, os preceptistas da agudeza propõem que todo signo exterior é metáfora que substitui ou copia o conceito interior. Alguns dos signos exteriores são falantes, outros mudos e outros compostos. Falantes são os orais e os escritos; signos mudos são as imagens das palavras pintadas e esculpidas; ou os gestos, que representam o movimento; os signos compostos misturam as duas espécies anteriores, sendo ao mesmo tempo falantes e mudos, como acontece com os emblemas, as empresas ou divisas. Na doutrina seiscentista da agudeza, há, portanto, seis maneiras básicas para representar um conceito agudo: $1^{\circ}$. por meio do conceito mental ou arquétipo; $2^{\circ}$. por meio da voz; $3^{\circ}$. por meio de caracteres escritos; $4^{\circ}$. por meio de gestos; $5^{\circ}$.por meio de representação do objeto e, ainda, $6^{\circ}$. por meio de uma maneira misturada (Tesauro, 1670; p.15). Passo a lhes falar delas.

A agudeza arquétipa é aquela que se desenha no ânimo com o pensamento. Por exemplo, imaginamos, como o rei Luís XII de França imaginou, um animal, o ouriço. Juntamente com a imagem do bicho, imaginamos uma inscrição em latim: Cominus et eminus. É essa agudeza mental que tentamos comunicar ao espírito dos outros através de signos exteriores: não é possível comunicá-la sem o recurso dos sentidos, que fundamentam a prescrição retórica e as demais formas da sociabilidade. Quando falamos essa agudeza ou a escrevemos ou a desenhamos ou a pintamos ou a esculpimos ou a imitamos com gestos, comunicamos que, assim como o ouriço tem espinhos, também temos armas com que nos defendemos e atacamos de perto e de longe.

Os Anjos podem, sem recorrer a nenhum meio sensível, produzir a imagem espiritual de seus pensamentos em outro espírito, tornando-se um e outro ora pintor ora pintura. Uma questão fundamental no século XVII foi a de saber se o Anjo pode conceber uma imagem ou se pode comunicá-la a outro do mesmo modo que o homem. Parece bizantino para o nosso positivismo, mas é metafísica cristã: o Anjo fala não com os signos dos conceitos, mas com os próprios conceitos, de maneira que para ele uma 
mesma coisa é significante e significada. Por isso, nenhum Anjo pode ser poeta, uma vez que é a significação de uma coisa por outra - a metáfora - que fundamenta a poesia e a representação em geral. Assim, os Anjos também não podem fabricar emblemas, empresas, divisas, hieróglifos, cifras, rebus, charadas enigmáticas, labirintos, metáforas, alegorias, imagens, figuras, pinturas, discursos, sermões, poemas, aulas, palestras sobre a agudeza seiscentista etc. Na Bíblia, porém, Deus demonstra que a natureza humana só se exprime como representação exterior, por isso inventa um Pão voador, uma Escada que sobe ao Céu, um Livro fechado com Sete Selos e outras imagens como maneira metafórica ou alegórica de agir na mente extática de seus Profetas. Dizia-se rotineiramente no século XVII que é próprio do homem amar o que admira, mas só admirar a verdade vestida, não a verdade nua (Tesauro, 1670, p. 17). Logo, o amor das imagens também é causa eficiente e instrumental das agudezas.

Robert Klein demonstrou, quando estudou os livros de empresas italianos do século XVI, que os preceptistas teorizam as imagens por meio da comparação do intelecto humano com o intelecto angélico (Klein, 1998; p.117-140). Do mesmo modo, para os preceptistas do século XVII, é a representação que define o homem. Também afirmam, com Aristóteles, que uma inteligência superior se caracteriza pela capacidade de estabelecer relações rápidas e inesperadas entre conceitos. A representação é uma mediação; na poesia da agudeza, uma mediação agudamente indireta.

A primeira espécie de representação exterior da agudeza é a fala. A fala aguda é dirigida ao ouvido, que goza com sua pintura, que tem o som por cor e a língua por pincel. A agudeza vocal deve ser elíptica e cheia de subentendidos, porque, nos ditos muito claros, perde o brilho, assim como as estrelas, que necessitam da escuridão para brilhar. Pressupõe-se, portanto, a condensação sutil e tendencialmente hermética. Segundo os seiscentistas, há um duplo gozo nas agudezas vocais, pois quem as emite tem o prazer de dar vida no intelecto de outro a um efeito do seu e, o ouvinte, o prazer de encontrar o que estava oculto. Aqui novamente está implicada a pragmática cortesã típica das monarquias absolutistas do século XVII, que define os produtores de agudezas como tipos urbanos dotados de instrumentos dialéticos e retóricos proporcionados pelo juízo prudente nas ocasiões em que a elegância discreta é a primeira norma da etiqueta. Por isso mesmo, o que especifica o sentido da agudeza vocal é o decoro, que considera a circunstância: uma mesma metáfora aguda pode ser fineza, brincadeira, jogo, ironia, obscenidade, sarcasmo ou agressão, conforme a ocasião e as pessoas circunstantes, o que implica seu regramento por um sistema de decoros externos que especificam as ocasióes do uso conveniente e o sentido adequado em cada uma delas. Como exemplo de agudeza vocal engenhosa, lembro uma carta de Vieira, datada de 1683, em que diz que a frota que naquele ano leva o açúcar da Bahia para Portugal 
carrega mais "queixas" que "caixas". Como exemplo de agudeza vocal imprudente, um caso contado pelo licenciado Manuel Pereira Rabelo, que no século XVIII escreveu uma "Vida do Excelente Poeta Lírico, o Doutor Gregório de Matos e Guerra" como notícia sobre os poemas que compilou e atribuiu ao poeta. Um dia, em Salvador, o jovem Sebastião da Rocha Pita se aproxima de Gregório de Matos e, depois de lhe dizer que passou o dia todo tentando escrever um soneto, declara: " falta uma rima para mim ", ao que Gregório imediatamente responde "capim". Segundo os preceptistas, as agudezas orais são "argumentos urbanos falazes" (Tesauro, 1670, p. 489). Nesse caso, a rima "capim” não é propriamente urbana. É uma agudeza perfeita, mas imprudente, porque feita expressamente com o propósito de ferir. Por isso mesmo, dizia-se no século XVII que o fim dos engenhosos costuma ser o hospital.

A segunda representação aguda exterior, a agudeza escrita, é uma imagem da agudeza vocal, como propõe Aristóteles. A agudeza escrita permite jogos ilimitados de conceitos e é considerada superior à vocal porque é durável. É dela que surgem, por exemplo, as inscrições agudas; os motes das empresas; as sentenças; as missivas lacônicas; os epigramas; os caligramas; os hierogramas e todos os variadíssimos jogos do engenho. Como na divisa dos Sabinos, S.P.Q.R, Sabinis Populis Quis Resistet?, que os romanos mantiveram, mas eliminando os sabinos, como diz Tesauro com muita graça. Alguém usou a letra $A$ para significar um filósofo ignorante, pois o A significava Boi. Héracles, o orador, fez um panegírico a Ptolomeu com o título grego PONU ENCOMION, isto é, Encômio da Tolerância; o rei apagou a primeira letra, escrevendo ONU ENCOMION, Encômio do Asno, para afirmar, bárbaro, que a tolerância é virtude de jumento e não de reis. Nesse mesmo gênero ablativo, um antigo, depois de ser interrogado acerca dos sinais pelos quais se reconhece o verdadeiro amigo, escreveu em latim a formulação em eco:

\section{AMORE \\ MORE \\ ORE \\ $R E$}

Significava que o amigo se conhece pelo afeto, pelos costumes, pelas palavras e pelas ações. Também se pode utilizar a escrita artificiosamente, de modo que o verso seja lido ao reverso, formando um palíndromo, isto é, desdizendo, quando é lido da direita para a esquerda, o que diz quando lido da esquerda para a direita , de modo que o louvor se torna censura. É o que acontece nos versos anônimos dirigidos a Henrique VIII da Inglaterra, marido de adúltera e adúltero : 


\section{Coniugium tibi Rex foecundent Numina longo} semine nec sterilis sit tibi progenies.

Em Il Cannocchiale Aristotelico, no capítulo em que trata da causa formal das figuras engenhosas, Tesauro lembra as "parole finte", as palavras fingidas, citando um trecho de Plauto (Pseud., 834-836) como exemplo de agudeza: "Haec ad Neptuni pecudes condimenta sunt. Terrestres pecudes CICIMANDRO condio: Aut HAPPALOPSIDE, aut CATARACTRIA". Mais excelentes exemplos de "palavras fingidas" acham-se nos sonetos de Quevedo contra Góngora. Neles, inventando barbarismos paródicos dos cultimos das Soledades, ataca as inovações de Góngora, imitando o estilo culto com "palavras fingidas" que fazem alusões obscenas. Por exemplo, assim começa um soneto que acusa Góngora de estuprar os poetas neotéricos latinos: "Sulquivagante, pretemor de Estolo,/ pues que lo expuesto al Noto solificas/y obtusas speluncas comunicas,/ despecho de las musas a ti solo,/ huye no carpa de tu Dafne Apolo/surculus slabros de teretes piscas,/ porque con tus per-versos damnificas/ los institutos de su sacro Tolo".

A agudeza escrita também pode ser pintura ou poesia, como argúcia de corpos figurados. Tesauro e outros preceptistas afirmam que a pintura, pondo frente aos olhos os simulacros das coisas, pela imitação material produz o engano da maravilha que agrada, pois consiste em fazer crer que o fingido é o verdadeiro, de modo que cenas que horrorizam deleitam. Comentando um verso de Petrarca no qual um soldado sedento bebe a água de um rio tinto do sangue dos mortos na batalha, o cardeal Sforza Pallavicino reitera, em seu tratado Arte dello Stile, o intelectualismo da doutrina do conceito engenhoso, afirmando que o principal gosto do intelecto é maravilhar-se, e não com a maravilha que decorre da ignorância das causas do efeito, caso em que a agudeza é uma imperfeição ou um tormento da razão, mas como meio de fazer ver o que antes se ignorava (Pallavicino, Arte dello Stile, 1647, p. 181). A poesia, como imitação metafórica, serve-se da pintura do que se vê para significar o que não se vê. Assim, se a imitação feita pela pintura agrada pela maravilha de que um leão fingido seja verdadeiro, a imitação poética produz a maravilha pela qual um leão verdadeiro é um homem forte, como quando se diz "Aquiles é um leão" (Tesauro, 1670, p. 16).

Quantos aos gestos, dizia-se no século XVII que as palavras são gestos sem movimento e que os gestos são palavras sem rumor: todo o corpo é uma página escrita com gestos prescritos segundo os gêneros (Tesauro, 1670, p. 24), como podemos ver na escultura religiosa, em que as várias posições dos corpos dos santos figuram os vários afetos da conformatio, o momento do contato extático com o corpo místico de Cristo. Em 1641, o oratoriano Sénault dedicou ao Cardeal Richelieu um tratado, De l'usage des passions, em que ensina uma retórica de gestos adequados às mais variadas circuns- 
tâncias, lembrando o dito de Tibério citado por Tácito nos Annales: Qui nescit fingere, nescit vivere (Sénault, 1987). Como na oratória, em que as palavras são próprias e metafóricas, naturais e vulgares, comuns e engenhosas: Quintiliano chamou de agudas as mãos de Hortênsio. Tesauro lembra que também era metafórico o gesto de erguer sobrancelhas, afetadamente severo e orgulhoso, do duúmviro de Cápua, que Cícero interpretou ironicamente como modo de fazer crer que sustentava a República com a sobrancelha, como Atlas sustenta o céu com os ombros. Conforme Tesauro, agudíssimo discurso de gestos metafóricos foi a disputa do sábio grego com o romano estúpido que é contada por Acúrcio, o jurista. Falando um ao outro com gestos, eles equivocavamse; e do equívoco nascia o prazer dos observadores. Diz Acúrcio, citado por Tesauro:

\begin{abstract}
Antes de os Gregos concederem as leis aos Romanos, mandaram um de seus sábios investigar se os romanos eram dignos de leis. Estes, depois de se aconselharem, enviaram um homem estúpido ao encontro do sábio grego(...). O Grego começou a disputa e ergueu um dedo para significar Deus é um só. E o néscio, acreditando que ele quisesse lhe furar um olho, ergueu dois, junto com o polegar, como naturalmente ocorre, para furar os dois olhos do Grego. Acreditou este que o Romano, com os três dedos, quisesse dizer Deus é Trino, e mostrou a palma da mão aberta para significar Tudo está nu e aberto frente a Deus. O estulto, pensando que ele queria dar-lhe um bofetão, levantou o punho para retribuir pancada com pancada. $O$ Grego imaginou que quisesse dizer Deus segura tudo na mão e, admirando a agudeza do engenho romano, julgou que aquela República era digna de leis (Tesauro, 1670, p. 25-26).
\end{abstract}

Também se utiliza a simples cor, sem figura, conferindo-lhe sentido alegórico, como foi usado pelos pintores antigos: amarelo significa o Sol; branco, a Lua; azul, Júpiter; verde, Vênus; vermelho, Marte; violeta ou púrpura, Mercúrio; negro, Saturno. As mesmas cores, na pintura, nos emblemas ou referidas na poesia, são metáforas: com o amarelo, relacionado ao Sol, significa-se /esplendor do sangue e riquezas/; com o branco, lunar, /Inocência e Fé/; com o azul, de Júpiter, /pensamentos altos e celestes/; com o verde, venéreo, /prazeres esperados ou conseguidos/; com o vermelho, marcial, Ningança e Valor/; com o púrpura, ou violeta, mercurial ou hermético, /Indústria e Arte/; com o negro, saturnino, /pensamento profundo de dor/. Da mistura das cores também se faz a mistura de pensamentos ou a indicação de propósitos, como os Rossi, os Bianchi e os Neri das facções guelfas e gibelinas do tempo de Frederico II. Quanto às empresas esculpidas, podemos lembrar, com Tesauro e outros, um elenco de objetos talhados em pedra, como os hieróglifos egípcios, ou cunhados em metal, como as me- 
dalhas; ou os feitos em relevo, como o escudo de Enéias; e, ainda, os esculpidos em mármore, marfim, ouro etc.; também os arcos, as colunas rostras, com imagens de inimigos encadeados, de rios e províncias subjugadas, de cidades vencidas, de coroas.Do mesmo gênero são as esculturas da proa de navios, como a Quimera, e outros monstros produzidos para ameaçar o mar; também são metáforas frisos, capitéis, cariátides, métopes e modilhões, na arquitetura.

Agudezas que lançam mão de "protótipo morto" fazem com que o original se torne imagem: como a dos Argonautas que, como pintou Valério Flaco, usavam despojos de Monstros e, como elmo, não simulacros, mas as próprias cabeças das feras que tinham abatido. No caso, como propõe Tesauro, os despojos são uma "empresa em original". Alciato deu o exemplo de Marco Antônio, que levava leões sob o carro, significando que havia domado os espíritos mais ferozes do Senado de Roma. Da mesma maneira, contase que uma romana mandou uma lebre a Marcial, lembrando o provérbio latino "Quem come lebre fica belo", para significar /És feio/, ao que o poeta respondeu:

\section{Edisti nunquam Gellia tu leporem.}

Conta-se que, da mesma maneira, utilizando uma empresa em original, Petrarca enviou a Laura algumas lebres acorrentadas, representando a si mesmo pelos animais porque, perdida a liberdade com o amor, tinha-se tornado presa da amada, fazendo as lebres falar.

Quanto às empresas figuradas por meio de personagem vivo ou de ação, como ensina Aristóteles, as metáforas representantes são mais agudas que as significantes, pois com a ação trazem o objeto para a frente dos olhos. Ele as chama justamente de prosomaton, "na frente do olho". Cita-se a sua admiração pelo engenho de Isócrates que, tendo de dizer "a Grécia deve estar tristíssima pela morte de seus cidadãos em Salamina", disse " a Grécia deve cortar os cabelos sobre o túmulo dos seus cidadãos em Salamina". Por ser metáfora continuada, a expressão é uma alegoria, podendo ser representada na pintura; por exemplo, pela imagem de uma mulher que corta os cabelos sobre o túmulo dos filhos. Nas letras seiscentistas, é uso muito valorizado, articulando-se na formulação metafórica como pintura de tipos, ações e cenas, na medida mesma em que a imagem é proposta como elemento da argumentação formulada como visualização sensorialmente dramática. Na medida em que a metáfora representante implica uma ação, pode ser usada como um entimema retórico, uma agudeza que funde o dito com o fato. Tesauro cita o exemplo do músico de Bolonha que, tendo ido assistir à apresentação de outro músico estrangeiro, que passava por um novo Orfeu, depois de longa espera ouviu uma voz fraca, trêmula e desafinada. Imediatamente, pôs uma capa de 
chuva no ombro, o que significou para todos os assistentes "o tempo é de chuva porque a rã coaxa”, caso em que a capa, como uma metáfora, também é um entimema satírico (Tesauro, 1670).

As discussões seiscentistas da agudeza têm por objeto principal a verossimilhança e o decoro da sua aplicação: nelas sempre está em pauta a questão do efeito persuasivo. Em posições por vezes inimigas, os autores das polêmicas concordam todos quanto ao artifício. Para eles, que evidentemente não são idealistas alemães, românticos adeptos do realismo socialista, é impensável a crítica da instituição retórica; discordam quanto ao limite dos usos. É o caso, fundamental, de Matteo Peregrini, autor de Delle Acutezze, che altrimenti spiriti, vivezze e concetti volgarmente si appellano (1639), que já referi. Ele propõe-se a teorizar "l'indiscreta affetazione delle acutezze", "a indiscreta afetação das agudezas", ou seja seu uso indecoroso. Por isso mesmo, admite seu uso, desde que regrado com proporção atenta à verossimilhança e ao decoro.

Como norma geral, Peregrini relaciona a agudeza com o gênero cômico para prescrever que, nos ditos espirituosos, que visam o delectare, ela é mais tolerável que nos argumentos sérios ( Peregrini, 1639; XII). Assim, discutindo o decoro dos gêneros baixos, afirma que é lícito o uso de agudezas empoladas e frias, evidentemente premeditadas, para fazer rir. Adverte, porém, que o defeito do juízo ou a inépcia do motejador, de um lado, e a feiúra da coisa motejada, de outro, tornam a agudeza mais desprazerosa que o mero prazer da sua novidade. Composições viciosamente agudas não são agradáveis, exceto para os que são privados de juízo e se deleitam com elas; por isso, a agudeza é sempre louvada pela "turba popular". Levada pelo efeito da novidade, a plebe é incapaz de ajuizar seu artifício e sua adequação. Também os adeptos do estilo "moderno", como Peregrini chama o discurso dos praticantes do conceptismo engenhoso hoje classificado de "barroco", os "infarinatti di lettere", louvam a agudeza sempre, porque, com sua presunção de sempre saber tudo, aplicam-na a torto e a direito, demonstrando que têm o juízo muito corrompido e que efetivamente pouco ou nada sabem. Nos dois casos, ignorância do vulgo e afetação de letrados, a agudeza é criticada segundo o critério do decoro, que necessariamente implica o do juízo. Os que não têm o juízo perfeito admiram-na pela novidade, que é grande, e que sempre produz o efeito de grandemente agradar. A feiúra do caso retórico necessita, contudo, para ser bem conhecida, uma "discretezza giudiciosa", uma "discrição judiciosa". No capítulo XII de seu tratado, como disse, Peregrini expõe " 25 cautelas para o uso das agudezas". Vou falar delas rapidamente, porque são pertinentes para conceituarmos a recepção contemporânea das representações seiscentistas. 
1. Devem ser evitados todos os gêneros de agudezas viciosas. No caso, Peregrini leva em conta o decoro interno e externo na qualificação de "vício". O vício é uma inépcia que fere a verossimilhança.

2. Deve-se evitar o excesso: "guardarsi dalla copia". O preceito vale principalmente nos gêneros baixos. No caso, Peregrini cita Cícero: A rareza dos ditos agudos distingue o orador do bufão

3. Deve-se evitar a afetação: "l'acutezze hanno de esser lungi da ogni colore d'affettazione". A agudeza decorre da rapidez do engenho; na afetação, evidencia-se o estudo ou a premeditação do dito agudo, que fica "frio" e perde a graça. Obviamente, em gêneros baixos, a afetação está prevista como ironia e sarcasmo - por exemplo, na composição de tipos vulgares, como o palhaço sem tato, que nunca pára de produzir ditos agudos e maledicentes .

4. Deve-se manter o decoro. Esta prescrição é nuclear e Peregrini cita Quintiliano com ela: "quem e sobre o quê e de quem e contra quem e o quê diga". É também o caso do sermão sacro que, segundo Vieira, no sermão da Sexagésima, de 1655, é transformado em cena de Plauto ou Terêncio quando as agudezas são dissociadas da teologia: “ Pregam palavras de Deus, mas não pregam a palavra de Deus”, diz Vieira dos sermões de seus inimigos, os dominicanos do Santo Ofício da Inquisição.

5. Deve-se evitar a agudeza nos lugares-comuns afetuosos. No caso, Peregrini refere as agudezas que evidenciam a preocupação de ser engenhosas ou que têm sabor de zombaria. $\mathrm{O}$ uso de agudezas com esse sentido é uma tópica corrente no século XVII na constituição de tipos infames, que preferem perder amizades a perder a oportunidade de mais uma vez demonstrar sua baixeza com ditos agudos que ferem. É o modo como o Licenciado Rabelo compõe a personagem Gregório de Matos como um tipo infame, em seu "Vida do Excelente Poeta Lírico, o Doutor Gregório de Matos Guerra". Por exemplo, na anedota em que o poeta, conversando com um senhor de engenho pernambucano, vê um boi com um só chifre. $\mathrm{O}$ animal pertence ao fazendeiro e Gregório diz que seu destino será o de sempre ser acusado de satírico, porque assim será interpretado se, naquele momento, disser que o animal é "boi de um corno só". Segundo Peregrini, a brincadeira nos lugares-comuns de afeto não só torna seu autor ridículo e indecoroso, como também impede a comoção e estraga totalmente o efeito pretendido pela arte .Contudo, como ironia, a agudeza produzida é muito eficaz, por exemplo, em declarações de amor jocosas ou em sátiras em que se finge a amizade para melhor agredir.

6. Deve-se usar a agudeza para fim relevante. Cícero distingue o bufão do engenho desdenhoso pela freqüência do uso das agudezas. 
7. Idem. Pessoas prudentes e graves usam pouco as agudezas jocosas e somente na conversação, quando respondem. Segundo Peregrini, produzi-las o tempo todo é índice de "engenho ventoso".

8. Deve-se evitar a agudeza em composição grave. "Grave", no caso, aplica-se à especificação da matéria do discurso. Por exemplo, na oratória deliberativa e na judicial, gêneros geralmente sérios, a agudeza não é tão própria quanto no gênero demonstrativo, que é grave, como louvor, e não-grave, como vituperação.

9. No gênero demonstrativo ou sofístico, de assunto ameno e ligeiro, ad ostentationem compositum, e que só demanda a audientium voluptatem, impõe-se a agudeza jocosa. O que também acontece na sátira - por exemplo, em Quevedo, Caviedes, Lord Rochester e na poesia atribuída a Gregório de Matos.

10. Evita-se a agudeza no gênero doutrinário puro (ou didático), porque o mestre sustenta uma persona grave, alheia a brincadeiras; contudo, admite-se a agudeza séria.

11. Evita-se a agudeza no discurso narrativo, ou histórico, porque prejudica o provável, logo, o verossímil. Se Plutarco escrevesse a vida de Alexandre com agudezas jocosas, o argumento heróico seria ridículo. Na obra histórica, é vetada a agudeza como obra do narrador, mas não a agudeza das próprias coisas narradas, devendo-se estabelecer diferença entre o objeto e a qualidade da sua eloqüência. Na narrativa fantástica, contudo, admite-se, quase que por definição.

12. Admite-se a agudeza como exercício, como as composições feitas por jovens para adquirir destreza técnica.

13. A comédia, segundo a qualidade das personagens, admite todos os gêneros de agudezas, principalmente as jocosas e as pungentes.

14. Agudezas sérias são próprias de composições sérias e são convenientes para ensinar e comover.

15. As agudezas jocosas convêm moderadamente na conversação; do contrário, tem-se a bufoneria .

16. As agudezas pungentes usam-se em todos os lugares em que se acuse, repreenda ou coisa do gênero. Lembro o poema atribuído a Gregório de Matos que, atacando Antônio Sousa de Meneses, governador da Bahia entre 1682-1684, explicita o uso da variante cômica maledicentia: "É já velho em Poetas elegantes/ O cair em torpezas semelhantes". O gênero demonstrativo não só admite tais torpezas agudas, mas as exige: no caso, Peregrini dá como exemplo o Apocolocyntosis, de Sêneca. 
17. As agudezas puras, ou graciosas, não têm lugar em tema que não seja por natureza apto para jogos e brincadeiras. Aliás, é inépcia não usá-las quando o tema é lúdico.

18. É mais tolerável a abundância de agudezas pungentes que o excesso de puros jogos, pois estes fazem do homem que os enuncia um tipo de engenho vão.

19. Os motes e os ditos agudos ridículos devem ser usados com muita circunscpecção não só quando escritos, mas em toda ocasião. Agudezas lascivas ou obscenas são próprias para pessoas vis .

20. Composições breves, como epigramas, sonetos e madrigais, exigem agudeza proporcionada ao seu tema, grave se o tema é grave; jocosa, se jocoso; irônica, se irônico; e ridícula ou maledicente, se o tema é baixo. O que é longo tem lugar para outros ornamentos e a falta da agudeza pode ser suplementada por eles. Por isso, nos discursos breves, a agudeza se impõe porque, se não ocorre, o discurso parece ter sido feito só para dizer a coisa, não para evidenciar o engenho.

21. Quando o principal fim é mover com o riso, as agudezas frias ou viciosas podem ser usadas, mas deve ser claramente evidente que se destinam ao riso.

22. O peso do afeto pode justificar o vício da figura que porventura esteja na agudeza. No caso, Peregrini discute a paronomásia, ou trocadilho, dando como exemplo um de Cícero contra Verres: "Deverias ter exigido um navio que navegasse contra os predadores, não com a presa".

23. As partículas "temperadas" podem justificar ou purgar o vício no uso e na substância das agudezas: "quase"; "como"; "talvez"; "diria que"; "seja-me permitido"; "parece"; "por assim dizer" etc. Como um remédio para o excesso, as partículas indicam o posicionamento da enunciação quanto ao tema e à circunstância do uso do discurso, revelando o conhecimento do defeito por parte da persona .

24. Nas composições longas, é escusável algum tipo de agudeza viciosa. Lição de Horácio, que afirma que nas composições longas é permitido insinuar o sono.

25. Nos recitativos, principalmente os feitos por jovens, tolera-se alguma licença na qualidade e na quantidade dos ditos agudos. $O$ defeito do juízo, se a agudeza é viciosa, é facilmente perdoado, pois alega-se a idade juvenil, naturalmente imprudente, segundo Peregrini e outros preceptistas.

\section{Nota}

* Professor Doutor de Literatura Brasileira da FFLCH-USP. 


\section{REFERÊNCIAS BIBLIOGRÁFICAS}

ANÔNIMO. Rhétorique a Hérennius. Trad. Henri Bornecque. Paris: Garnier, s/d. ARISTÓTELES. Rhétorique. Trad. Médéric Dufour. Paris: Belles Lettres, 1931. . Poétique. Trad. de J. Hardy. Paris: Belles Lettres, 1952.

. Organon. I - Catégories. II - De l'interprétation. Trad. J. Tricot. Paris: Librairie Philosophique J. Vrin, 1936.

. Éthique a Nicomaque. Trad. J. Tricot. Paris: Librairie Philosophique J. Vrin, 1967.

CÍCERO, M. T. De l' orateur. Trad. François Richard. Paris: Garnier, s/d.

ELIOT, T.S. The Varieties of Metaphysical Poetry. The Clark Lectures at Trinity College, Cambridge, 1926 and The Turnbull Lectures at The Johns Hopkins University, 1933. New York / San Diego / London: Harcourt Brace \& Company, 1994.

GRACIÁN, B. Artifício y Arte de Ingenio. Obras Completas. Madrid: Aguilar, 1960.

KLEIN, R. A Teoria da Expressão Figurada nos Tratados Italianos sobre as Imprese, 1555-1612. A Forma e o Inteligível. Escritos sobre o Renascimento e a Arte Moderna. Trad. Cely Arena. Revisão técnica de Leon Kossovitch e Elisa Angotti Kossovitch. São Paulo: EDUSP, 1998. cap. 4, p. 117-140.

PALLAVICINO, S. Arte dello Stile, ove nel cercarsi l' Ideal dello scrivere Insegnativo. Roma: 1647.

PEREGRINI. M. Delle Acutezze che altrimenti spiriti, vivezze e concetti volgarmente si appellano (1639). In: RAIMONDI, E. Trattatisti e Narratori del Seicento. Milano/Napoli: Riccardo Ricciardi, 1960.

QUINTILIANO, M. F. Institution oratoire. Trad. Henri Bornecque. Paris: Garnier, 1933, 4 vol.

SÉNAULT, J.-F. De l'usage des passions (1641). Tours: Fayard, 1987.

SÊNECA O RETOR. Controverses et suasoires. Trad. Henri Bornecque. Paris: Garnier, 1932, 2 vol.

TESAURO, E. Il Cannocchiale Aristotelico o sia Idea dell'arguta et ingeniosa elocutione che serve à tutta l' arte oratoria, lapidaria; et simbolica esaminata co' principii del divino Aristotele. $5^{\text {a }}$ impressione. Torino: Bartolomeo Zavatta, 1670.

HANSEN, João Adolfo. Rhétorique de la pointe.

RÉSUMÉ: Le texte est une exposition de la doctrine rhétorique de la pointe au XVIIe siècle. La pointe est l'effet de sens inatendu qu'on obtient par moyen 
de la condensation métaphorique de concepts eloignés. En établissant la liaison entre la pratique de la pointe et la rationalité de Cour des monarchies absolues du XVIle siècle, le texte en donne des exemples avec des poètes, orateurs et preceptistes, comme Góngora, Gracián, Donne, Shakespeare, Gregório de Matos, Vieira, Tesauro, Pallavicino, Peregrini etc., pour démontrer avec eux l'appropriation et l'application des auctorités rhétoriques grecques et latines à la production du "beau éfficace".

MOTS-CLEFS: rationalité de Cour; rhétorique; métaphore; pointe; concept. 